\title{
Physicians' and nurses' perceptions and attitudes toward sickle cell disease patients in Jazan, Saudi Arabia
}

\author{
Ahmad A. Hazzazi, MBBS, Mohssen H. Ageeli, MBBS, Khalid A. Sharahili, MBBS, Hesham M. Hamaly, MBBS \\ Mohammad H. Aqeeli, MBBS, Tawfeeq I. Altherwi, MBBS, FRCPC, Mohammed Bakkar, MD, Hafiz Malhan, MD, SBIM.
}

\begin{abstract}
الأهداف : استكشاف تصورات الأطباء والممرضات وسلو كهم تجاه مرضى فقر الدم المنجلي في منطقة جازان في المملكة العربية السعودية.

المنهجية: دراسة مقطعية أجريت في جازان في المملكة العربية السعودية

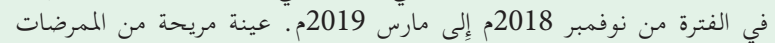

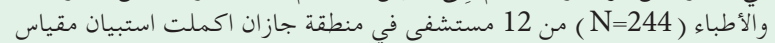

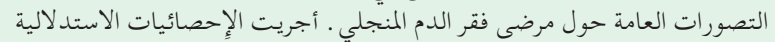

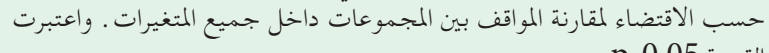
القيمة p p pos 0.05 مهمه.

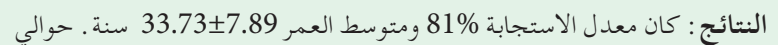

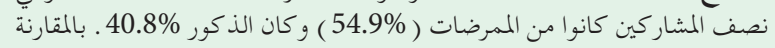

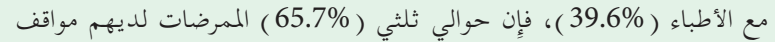

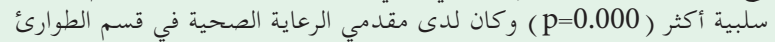
سلوك سلبي أعلى من مقدمي الرعاية الصحيّة في قسم الأطفال (

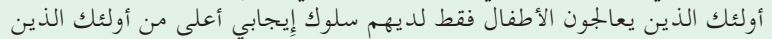

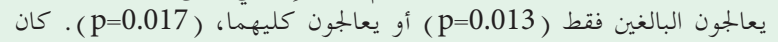

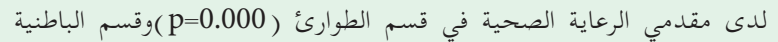
( درجات في مقياس السلوك المثيرة للقلق أعلى من مقدمي الرعاية (p=0.001)

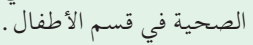

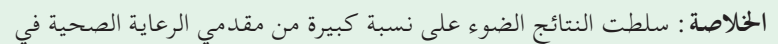

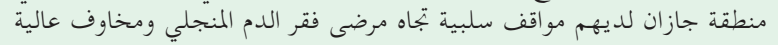

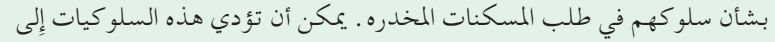

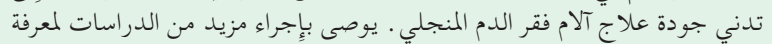

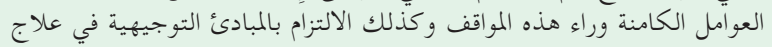

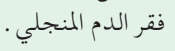

Objectives: To explore physicians' and nurses' perceptions and attitudes toward sickle cell patients in Jazan, Kingdom of Saudi Arabia (KSA).

Methods: A cross-sectional study conducted in Jazan, KSA from November 2018 to March 2019. A convenience sample of nurses and physicians $(\mathrm{N}=244)$ from 12 hospitals in Jazan region completed the general perceptions about sickle cell disease patients scale questionnaire. Inferential statistics were conducted as appropriate to compare attitudes among groups within all variables. A $p<0.05$ was considered significant.
Results: The response rate was $81 \%$. The mean age was $33.73 \pm 7.89$ years. Approximately, half of the participants were nurses $(54.9 \%)$ and $40.8 \%$ were males. In comparison with physicians (39.6\%), approximately two-thirds $(65.7 \%)$ of nurses have more negative attitudes $(p=0.000)$. Emergency healthcare providers have more negative attitudes than providers in the pediatric department $(p=0.043)$. Those treating primarily children had higher positive attitude than those treating adults $(p=0.013)$ or treating both, $(p=0.017)$. Emergency providers $(p=0.000)$, and internal medicine providers $(p=0.001)$, had higher concern-raising behaviors' scale scores than pediatric providers.

Conclusion: Findings highlight a significant proportion of providers in Jazan region, KSA, to have negative attitudes toward and high concerns about drug-seeking behaviors among sickle cell patients. These attitudes can contribute to lower quality of care for people with sickle cell disease. Further studies are recommended to find out the factors behind these attitudes as well as the adherence to guidelines in the management of sickle cell disease.

Keywords: perceptions, attitudes, healthcare providers, physicians, nurses, Jazan, sickle cell patients

\section{Saudi Med J 2020; Vol. 41 (8): 841-848} doi: $10.15537 /$ smj.2020.8.25183

From the Faculty of Medicine (Hazzazi, Ageeli, Sharahili, Hamaly, Aqeeli); from the Department of Emergency Medicine (Altherwi), Jazan University, and from the Department of Hematology (Bakkar, Malhan), Prince Mohammed Bin Nasser Hospital, Jazan, Kingdom of Saudi Arabia.

Received 12th March 2020. Accepted 24th June 2020.

Address correspondence and reprint request to: Dr. Ahmad A. Hazzazi, Faculty of Medicine, Jazan University, Jazan, Kingdom of Saudi Arabia.E-mail:Ahmad.Amdamr@gmail.com

ORCID ID: https://orcid.org/0000-0001-5148-6184 
$S^{\mathrm{i}}$ ickle cell disease (SCD) is considered the most common serious heritable hematological disorder among humans. ${ }^{1}$ Worldwide, SCD is one of the most common single-gene disorders. Globally, one-third of a million newborns born with an intense type of this disorder annually. ${ }^{2}$ It is the third principal cause of hospital admissions among children and a major cause of mortality among them during the hospital stay in Africa. ${ }^{3}$ In Kingdom of Saudi Arabia (KSA), the estimated prevalence of SCD through the Saudi premarital screening program was 3.8 per 1000 of the population. ${ }^{4}$ While newborn screening estimated the prevalence of SCD to be $2.6 \%$ in the Eastern region, KSA. ${ }^{5}$ An average prevalence rate of SCD of 48.34 per 1000 of the population was demonstrated in a study that examined more than 12 million sickle tests over 5 years in KSA. Jazan, KSA, has the highest prevalence of sickle cell trait and the third highest prevalence of SCD in KSA. ${ }^{4}$ In a recently published study conducted in Jazan region, KSA, SCD was the most common cause of hospitals' admissions with a percentage of more than $20 \%$ of the total admissions in medicine and pediatric departments. ${ }^{6}$ It is known that healthcare providers' attitudes toward patients can affect the quality of care as negative attitudes can be a barrier to proper pain management. ${ }^{7-9}$ More respect and trust from physicians to sickle cell patients are believed to be associated with proper management and less frustration and mistrust among sickle cell patients. ${ }^{10,11}$ The most frequent clinical complications of this disease are the vaso-occlusive crises (VOC) ${ }^{12,13}$ During VOC the patients seek strong analgesics to relieve their pain. Despite their need for strong analgesics, the healthcare providers' concerns about addiction among sickle cell patients and fear of contributing to opiate use disorder and addiction cause the healthcare providers to deliver suboptimal analgesia. These concerns are considered an important barrier to effective pain control. ${ }^{14}$ Furthermore, the negative attitudes of health care providers found to be associated with less adherence to sickle cell pain crises management recommendations. ${ }^{10}$ Another issue was the bad effect of the negative attitudes on the psychiatric conditions of the patients. ${ }^{15}$ Different educational interventions using videos and lectures have been implemented to improve the perceptions and attitudes of healthcare providers

Disclosure. This study was funded by the Deanship of Scientific Research [Grant no: FR6-110], Jazan University, Jazan, Kingdom of Saudi Arabia. toward sickle cell patients and found to be effective with encouraging results in the increment of positive attitudes and decrement of negative attitudes. ${ }^{7,16}$ In this setting, we aim to explore physicians' and nurses' perceptions of sickle cell patients, and to assess their attitudes toward sickle cell patients to provide a base for future interventions and plans to improve sickle cell patients' status in Jazan, KSA.

Methods. A cross-sectional study was conducted between November 2018 and March 2019 to evaluate the perceptions and attitudes toward sickle cell patients among physicians and nurses in Jazan region, KSA. A convenience sampling technique was used to recruit participants. The participants included were physicians (consultants, specialists, and residents) and registered nurses who were working in the internal medicine, pediatrics, and emergency departments in 12 hospitals (secondary, tertiary, and private hospitals) located in different areas of Jazan region. Healthcare providers from outside Jazan, KSA, or working in departments other than the included departments were excluded. The participants were approached during their work and break times. We used a previously validated questionnaire (the general perceptions about SCD patients scale) which was validated by Haywood et $\mathrm{al}^{7}$ among internal medicine physicians and among emergency providers by Freiermuth et al, ${ }^{9}$ to assess physicians' and nurses' perceptions of sickl cell patients in Jazan region, KSA. A total of 300 questionnaires were distributed and collected by the co-investigators by 2 means; i) printed questionnaire papers; ii) electronic questionnaire distributed through WhatsApp (WhatsApp Inc, Mountain View, California, USA) and e-mail. The questionnaires were self-administered by the participants. The questionnaire included 2 parts. First, physicians' and nurses' demographic characteristics including their gender, age, worksite, practice level, type of patients they treat, years of experience, and the number of sickle cell patients they treat or supervising their treatment during a typical week. Second, was the general perceptions about SCD patients scale which includes 5-Likert scale questions to assess physicians' and nurses' attitudes toward sickle cell patients. The questions broke out into 3 scales; negative, positive, and concern-raising behavior attitudes scales. Negative attitudes were measured by 6 questions that reflect how the physicians are negatively perceiving SCD patients (for example, what percentage of patients with SCD are trying to manipulate you or other providers?). Similarly, positive attitudes were measured by 4 questions that reflect how the physicians are positively perceiving 
SCD patients (for example, what percentages of patients with SCD are satisfying to take care of?). Response options for questions measuring negative and positive attitudes were as the following: $<5 \%, 6 \%$ to $20 \%, 21 \%$ to $50 \%, 51 \%$ to $75 \%,>75 \%$. For the measurement of concern-raising behaviors, 7 questions that reflect how the physicians are perceiving some of SCD patients' behaviors as drug-seeking behaviors. An example of these questions is SCD patient changes his/her behavior (namely, appears in greater distress) when a provider walks in the room? The responses to these questions were 5-point Likert scale ranging from strongly agree to disagree. For the calculation of scores in each attitude scale, all the questions for a given scale were normalized to a score out of 100 . By which, if the participant answers the highest possible score for every question that gets a 100 . If the participant gives the lowest possible score on each question that is a 0 . Thus, higher scores on negative attitude scale indicated more negative attitude toward sickle cell patients, higher scores on positive attitude scale indicated a more positive attitude toward sickle cell patients and higher scores concern-raising behavior scale indicated a greater belief that certain SCD patients' behaviors raise healthcare providers' concern that the patients are inappropriately drug-seeking. Written consents were obtained from all participants. The study was approved by the King Fahad Central Hospital Institutional Review Board (IRB) as well as Jazan Hospital IRB, KSA.

Statistical analysis. Descriptive statistics were calculated. For categorical variables, frequencies and percentages were calculated. Means and standard deviations were calculated for continuous variables. Since the data was not normally distributed after the use of Kolmogorov Simonov and Shapiro tests, the 3 attitudinal scales' scores were compared across demographic variables using non-parametric tests including the Mann-Whitney test to compare means of variables with 2 categories and Kruskal-Wallis test to compare means of variables with more than 2 categories as appropriate and the results reported as median (interquartile range $[\mathrm{IQR}]$ ). A post-hoc multiple comparison procedure was performed to assess pairwise differences among the levels of each factor with a significant overall Kruskal-Wallis test. Two-sided $p$-value was set at a level of $<0.05$ to indicate statistical significance. Multivariate analysis using multiple logistic regression was conducted to find out the predictors of attitudes only for the significant factors in univariate analysis. Statistical Package for the Social Sciences program, version 25 (IBM Corp, Armonk, NY, USA) was used to carry out all statistical analyses.
Results. A total of 244 questionnaires were completed with a response rate of $81 \%$. The mean age of the participants was $33.73 \pm 7.89$ years. Approximately, $41.8 \%$ of participants were males. About half of the participants were nurses $(54.9 \%)$ and the other half were physicians with different levels of practice namely, consultants $(8.2 \%)$, specialists $(16.4 \%)$, and residents $(20.5 \%)$. The majority were working in the department of internal medicine $(54.5 \%)$ while others are working in the emergency department (ED) (19.3\%) and pediatric department $(26.2 \%)$. On average, participants have been treating SCD patients for 5 year, $(\mathrm{IQR}=3-10)$ years. Physicians and nurses participated in the treatment of (5.50, IQR=3-10) sickle cell patients per week. According to the type of patients treated, $48.4 \%$ were participating primarily in the treatment of adult patients, $20.5 \%$ were treating primarily pediatrics and $31.1 \%$ were participating in the treatment of both. These demographics are summarized in Table 1. Summary of the mean scores of the 3 attitude scales presented in Table 2 . It showed that there is a statistically significant difference between nurses and physicians in the negative attitude mean scores $(p=0.003)$ in which the nurses had higher scores than physicians. However, no statistically significant difference between nurses and physicians in the positive attitude mean scores and concernraising behavior scale. The effects of demographic characteristics of the participants on negative attitude

Table 1 - Demographic variables of the study participants.

\begin{tabular}{|c|c|}
\hline Variable & $\mathrm{n}(\%)$ \\
\hline Age $($ mean $\pm S D)$ (years) & $33.73 \pm 7.89$ \\
\hline \multicolumn{2}{|l|}{ Gender } \\
\hline Male & $102(41.8)$ \\
\hline Female & $142(58.2)$ \\
\hline \multicolumn{2}{|l|}{ Department } \\
\hline Internal medicine & $133(54.5)$ \\
\hline Emergency & $47(19.3)$ \\
\hline Pediatric & $64(26.2)$ \\
\hline \multicolumn{2}{|l|}{ Level of practice } \\
\hline Consultant & $20 \quad(8.2)$ \\
\hline Specialist & $40(16.4)$ \\
\hline Resident & $50(20.5)$ \\
\hline Nurse & $134(54.9)$ \\
\hline \multicolumn{2}{|l|}{ Type of patients treated } \\
\hline Primarily adults & $118(48.4)$ \\
\hline Primarily children & $50(20.5)$ \\
\hline Both & $76(31.1)$ \\
\hline \multicolumn{2}{|c|}{ Years of experience in treating sickle cell patients ${ }^{\dagger}$} \\
\hline$<5$ years & $116(49.2)$ \\
\hline$\geq 5$ years & $120(50.8)$ \\
\hline Sickle cell patients treated/week ${ }^{*}$ & $5.50(3-10)$ \\
\hline
\end{tabular}


Table 2 - Summary of mean scores of attitude scales for all respondents, for nurses and physicians $(\mathrm{N}=244)$.

\begin{tabular}{lcccc}
\hline Attitude scales & Total & Nurses $(\mathbf{n}=110)$ & Physicians $(\mathbf{n}=134)$ & $P$-value \\
\hline Negative attitude scale & $39.05 \pm 21.15$ & $42.71 \pm 20.63$ & $34.58 \pm 21.01$ & 0.003 \\
Positive attitude scale & $44.58 \pm 21.66$ & $43.13 \pm 21.32$ & $46.33 \pm 22.03$ & 0.225 \\
Concern-raising behaviors scale & $51.78 \pm 23.02$ & $52.59 \pm 22.87$ & $50.80 \pm 23.28$ & 0.547 \\
\hline
\end{tabular}

Values are presented as mean $\pm \mathrm{SD}$. $P$-values indicate statistical significance $(p<0.05)$

Table 3 - Association between demographic characteristics of the participants and negative attitude scale.

\begin{tabular}{|c|c|c|c|}
\hline Character & Median & IQR & $P$-value \\
\hline \multicolumn{4}{|l|}{ Gender } \\
\hline Male & 37.49 & $(20.83)-(54.15)$ & \multirow{2}{*}{$0.482^{*}$} \\
\hline Female & 41.65 & $(24.99)-(54.15)$ & \\
\hline \multicolumn{4}{|l|}{ Department } \\
\hline Internal medicine & 41.65 & $(24.99)-(54.15)$ & \multirow{3}{*}{$0.015^{* *}$} \\
\hline Emergency & 49.98 & $(20.83)-(66.64)$ & \\
\hline Pediatric & 33.32 & $(20.83)-(45.82)$ & \\
\hline \multicolumn{4}{|c|}{ Provider level of practice } \\
\hline Consultant & 37.49 & $(10.41)-(37.49)$ & \multirow{4}{*}{$0.002^{* *}$} \\
\hline Specialist & 45.82 & $(24.99)-(54.15)$ & \\
\hline Resident & 27.07 & $(16.66)-(41.65)$ & \\
\hline Nurse & 45.81 & $(28.11)-(58.31)$ & \\
\hline \multicolumn{4}{|c|}{ Experience's duration in treating sickle cell disease patients } \\
\hline$<5$ years & 45.82 & $(29.16)-(58.31)$ & \multirow{2}{*}{$0.003^{*}$} \\
\hline$\geq 5$ years & 33.32 & $(20.83)-(49.98)$ & \\
\hline \multicolumn{4}{|l|}{ Type of patients treated } \\
\hline Adults & 41.65 & $(24.99)-(54.15)$ & \multirow{3}{*}{$0.067^{* *}$} \\
\hline Children & 33.32 & $(20.83)-(45.82)$ & \\
\hline Both & 45.82 & $(20.83)-(60.39)$ & \\
\hline \multicolumn{4}{|c|}{$\begin{array}{c}\text { *Results of Mann-Whitney test for 2-independent samples. *Results of } \\
\text { the Kruskal-Wallis test for several independent samples, } p<0.05 \text {. } \\
\text { IQR: interquartile range }\end{array}$} \\
\hline
\end{tabular}

scores are demonstrated in Table 3. Overall, females have a more negative attitude toward sickle cell patients. However, it does not reach statistical significance $(p=0.482)$. Likewise, treating adults, pediatrics sickle cell patients, or both, does not affect negative attitude scores $(p=0.067)$. Furthermore, nurses and physicians with less than 5 years of experience have a more negative attitude than those with 5 or more years of experience $(p=0.003)$. The scores of the negative attitude scores significantly differ based on the department $(p=0.015)$ and the provider's level of practice $(p=0.002)$. Results of post hoc multiple comparison tests showed that providers working in the emergency and internal medicine departments $(p=0.043)$ have a more negative attitude toward sickle cell patients than the providers in the pediatric department $(p=0.005)$. In addition, nurses had more negative attitudes than residents $(p=0.000)$ and similar findings between specialists and residents $(p=0.019)$ in negative attitudes. As long as the median of the negative attitude score is concerned, approximately two-thirds (65.7\%) of nurses have scores above the median compared to approximately one third (39.6\%) of physicians $\left(\mathrm{X}^{2}=13.92, p=0.000\right)$. Positive attitude scores statistically different according to the department $(p=0.043)$ and type of sickle cell patients treated $(p=0.026)$ as shown in Table 4. Multiple comparisons revealed that pediatric department providers have more positive attitude scores than those working in $\operatorname{ED}(p=0.019)$. Additionally, those treating mainly children have more positive attitudes $(p=0.013)$ than those treating mainly adults sickle cell patients or treating both, children and adults $(p=0.017)$. In terms of concern-raising behaviors, no significant association found between the participants' demographics and the attitude scores except for the department $(p=0.043)$ as demonstrated in Table 5. Providers in the departments of emergency and internal medicine have higher scores in concern-behavior $(p=0.000)$ than pediatric department providers $(p=0.001)$. Pearson correlation was used to examine whether the 3 scores are related to the age, years of experience in treating sickle cell patients, and the number of sickle cell patients treated per week. The analysis indicated that: i) increasing the number of patients treated per week is positively correlated with positive scores among physicians $(\mathrm{r}=0.286, p=0.007)$ but not the nurses ( $\mathrm{r}=-0.167, p=0.061)$; ii) increasing the years of experience is negatively correlated to the scores of negative attitudes $(\mathrm{r}=-0.210, p=0.001)$ and concernraising behavior $(\mathrm{r}=-0.193, p=0.003)$; iii) negative correlation found between increasing the age and negative attitudes scores ( $\mathrm{r}=-0.042, p=0.519)$ and concern-raising behavior scores $(\mathrm{r}=-0.053, p=0.416)$. Moreover, increasing age is associated with higher positive attitude scores $(\mathrm{r}=0.072, p=0.269)$. However, this weak correlation was not statistically significant. Significantly associated variables with attitudes were entered into the multivariate analysis. The variables entered in the model were the department, provider type, years of experience in treating sickle cell patients, and types of patients treated. However, gender was 
Table 4 - Association between demographic characteristics of the participants and positive attitude scale.

\begin{tabular}{|c|c|c|c|}
\hline Character & Median & IQR & $P$-value \\
\hline \multicolumn{4}{|l|}{ Gender } \\
\hline Male & 50.0 & $(25)-(62.50)$ & \multirow{2}{*}{$0.612^{*}$} \\
\hline Female & 43.75 & $(25)-(62.50)$ & \\
\hline \multicolumn{4}{|l|}{ Department } \\
\hline Internal medicine & 43.75 & $(25)-(56.25)$ & \multirow{3}{*}{$0.043^{* *}$} \\
\hline Emergency & 37.50 & $(25)-(50)$ & \\
\hline Pediatric & 50.0 & $(31.25)-(62.50)$ & \\
\hline \multicolumn{4}{|c|}{ Provider level of practice } \\
\hline Consultant & 50.0 & $(26.56)-(60.94)$ & \multirow{4}{*}{$0.306^{* *}$} \\
\hline Specialist & 50.0 & $(25)-(68.75)$ & \\
\hline Resident & 43.75 & $(25)-(51.56)$ & \\
\hline Nurse & 43.75 & $(25)-(56.25)$ & \\
\hline \multicolumn{4}{|c|}{ Experience's duration in treating sickle cell disease patients } \\
\hline$<5$ years & 50.0 & $(31.25)-(56.25)$ & \multirow{2}{*}{$0.162^{*}$} \\
\hline$\geq 5$ years & 43.75 & $(25)-(62.50)$ & \\
\hline \multicolumn{4}{|l|}{ Type of patients treated } \\
\hline Adults & 43.75 & $(25)-(56.25)$ & \multirow{3}{*}{$0.026^{\dagger}$} \\
\hline Children & 50.0 & $(40.63)-(62.50)$ & \\
\hline Both & 43.75 & $(25)-(62.50)$ & \\
\hline \multicolumn{4}{|c|}{$\begin{array}{l}{ }^{*} \text { Results of Mann-Whitney test for two-independent samples, " Results } \\
\text { of the Kruskal-Wallis test for several independent samples. } p<0.05 \text {, IQR: } \\
\text { interquartile range }\end{array}$} \\
\hline
\end{tabular}

not entered in the analysis as there was no statistically significant difference between males and females in all attitude scales. Medicine department attitudes did not significantly differ from those in the pediatric department $(p=0.131)$. However, in comparison with pediatric health professionals, emergency care providers were 3.32 times as likely to have more negative attitudes $(p=0.026)$. Nurses were more than 2 times more likely to have negative attitudes than physicians $(p=0.001)$. Further, the more experience in the treatment of sickle cell patients, the less likely to have negative attitudes toward SCD patients $(p=0.001)$, (Table 6).

Discussion. Positive attitude. During emergency visits and inpatient admissions, sickle cell patients might face different kinds of attitudes that can affect their management and their improvement. ${ }^{7,8,17}$ In our study, the positive attitude scale revealed that physicians and nurses have a less positive attitude toward sickle cell patients. We found that pediatric healthcare providers and those who take care of children patients primarily have a more positive attitude than emergency healthcare providers and those who take care of adult patients or both, adult and pediatric patients. Similar results were reported by Glassberg et al, ${ }^{10} \mathrm{He}$ also found that those treating more sickle cell patients per week have a more negative attitude and less quality in sickle cell pain management. However, our finding is contradictory to
Table 5 - Association between demographic characteristics of the participants and concern-raising behavior scale.

\begin{tabular}{|c|c|c|c|}
\hline Character & Median & IQR & $P$-value \\
\hline \multicolumn{4}{|l|}{ Gender } \\
\hline Male & 53.55 & $(33.02)-(67.83)$ & \multirow{2}{*}{$0.480^{* *}$} \\
\hline Female & 53.55 & $(39.27)-(67.84)$ & \\
\hline \multicolumn{4}{|l|}{ Department } \\
\hline Internal medicine & 57.12 & $(39.27)-(67.84)$ & \multirow{3}{*}{$0.000^{* *}$} \\
\hline Emergency & 60.71 & $(44.63)-(78.55)$ & \\
\hline Pediatric & 42.84 & $(24.99)-(60.69)$ & \\
\hline \multicolumn{4}{|c|}{ Provider level of practice } \\
\hline Consultant & 51.77 & $(22.31)-(67.83)$ & \multirow{4}{*}{$0.928^{* *}$} \\
\hline Specialist & 53.55 & $(32.13)-(66.95)$ & \\
\hline Resident & 57.12 & $(39.27)-(71.41)$ & \\
\hline Nurse & 53.55 & $(39.27)-(67.84)$ & \\
\hline \multicolumn{4}{|c|}{ Experience's duration in treating sickle cell disease patients } \\
\hline$<5$ years & 57.12 & $(39.27)-(67.83)$ & \multirow{2}{*}{$0.395^{*}$} \\
\hline$\geq 5$ years & 49.99 & $(36.59)-(71.40)$ & \\
\hline \multicolumn{4}{|l|}{ Type of patients treated } \\
\hline Adults & 57.12 & $(39.27)-(71.41)$ & \multirow{3}{*}{$0.136^{* *}$} \\
\hline Children & 46.42 & $(32.13)-(60.70)$ & \\
\hline Both & 57.13 & $(39.27)-(69.63)$ & \\
\hline \multicolumn{4}{|c|}{$\begin{array}{c}\text { *Results of Mann-Whitney test for two-independent samples. "Results of } \\
\text { the Kruskal-Wallis test for several independent samples. } p<0.05 \text {, } \\
\text { IQR: interquartile range }\end{array}$} \\
\hline
\end{tabular}

Glassberg et $\mathrm{al},{ }^{10}$ at this point. Sickle cell patients in our area are known to most health care professionals due to their frequent visits, this could build positive relationships that are possibly reflected in our results.

Negative attitude. Nurses had a more negative attitude toward SCD patients than physicians do. This finding supported by many previous studies that found negative attitudes were higher among nurses than physicians. Nurses' negative attitude can be explained by that nurses spending more time with sickle cell patients. ${ }^{16,18}$ Other factors that may also contribute to nurses' negative attitudes include: they are the first responders to the patients' complaints, patients are blaming them for poor pain control, verbal abuse from the patients, and less participation in educational activities. ${ }^{18}$ Moreover, nurses thought that sickle cell patients complain more than other patients and they do not use analgesics appropriately. ${ }^{19}$ However, this finding does not match what Ratanawongsa et $\mathrm{al}^{, 20}$ had concluded, by using different scale they found that nurses had a more positive attitude toward sickle cell patients than other healthcare providers. However, this is a single study that does fit with others. We found that emergency and internal medicine providers expressed more negative attitude than pediatric providers. Moreover, when compared to the internist, emergency providers exhibited attitudes that are more negative. In previous studies, it has been found that emergency 
Table 6 - Predictors of positive and negative attitude scales in multivariate analysis (logistic regression).

\begin{tabular}{|c|c|c|c|c|}
\hline \multirow[t]{2}{*}{ Variable } & \multicolumn{2}{|c|}{ Negative attitudes } & \multicolumn{2}{|c|}{ Positive attitudes } \\
\hline & OR $(95 \% \mathrm{CI})$ & $P$-value & OR $(95 \% \mathrm{CI})$ & $P$-value \\
\hline \multicolumn{5}{|l|}{ Department } \\
\hline Pediatric & Ref & Ref & Ref & Ref \\
\hline Emergency & $3.32(1.15-9.59)$ & 0.026 & $0.94(0.35-2.56)$ & 0.908 \\
\hline Medicine & $2.12(0.80-5.61)$ & 0.131 & $1.78(0.71-4.51)$ & 0.222 \\
\hline \multicolumn{5}{|l|}{ Provider type } \\
\hline Physician & Ref & Ref & Ref & Ref \\
\hline Nurse & $2.73(1.51-4.92)$ & 0.001 & $0.85(0.48-1.50)$ & 0.580 \\
\hline \multicolumn{5}{|l|}{ Experience } \\
\hline$<5$ years & Ref & Ref & Ref & Ref \\
\hline$\geq 5$ years & $0.36(0.21-0.64))$ & 0.001 & $0.70(0.40-1.20)$ & 0.191 \\
\hline \multicolumn{5}{|l|}{ Type of patients treated } \\
\hline Primarily children & Ref & Ref & Ref & Ref \\
\hline Primarily adults & $1.08(0.36-3.19)$ & 0.892 & $0.29(0.10-0.86)$ & 0.026 \\
\hline Both & $0.72(0.24-2.14)$ & 0.555 & $0.29(0.10-0.83)$ & 0.021 \\
\hline
\end{tabular}

OR: odds ratio, CI: confidence interval, Ref: reference group

providers posed higher negative attitudes than other providers and less understanding of SCD problems than inpatient providers from the patients' perspective..$^{20-22}$ Glassberg et al, ${ }^{10}$ found emergency healthcare providers with more negative attitudes have less adherence to sickle cell management guidelines when compared to those with better attitudes. The negative attitudes of emergency providers may be attributed to the overrepresentation of sickle cell patients at ED and the high prevalence of addiction disorders among them..$^{9,10,18,20}$ Nevertheless, it seems to be like a vicious circle, the negative attitudes of emergency providers result in improper management of sickle cell pain, and thereafter, repeated ED visits seeking pain relief. ${ }^{7,8,17}$ Different interventions programs had been implemented to improve healthcare providers' attitudes including 8-minute video consisted of discussion between physician expert and sickle cell patients about sickle cell pain management difficulties and misconceptions, the high-intensity educational program includes 2 and half days of educational and experimental intervention using videos about sickle cell patients' experience in comparison to low-intensity program consist of 90 minutes using same contents, and 60 minutes educational lectures together with 30 minutes informational updates and refresher talks together with website modules. ${ }^{7,16,18,23}$ All these interventions have proven their efficacy in improving positive attitudes and reducing negative attitudes toward sickle cell patients. ${ }^{7,16,18,23}$

Concern-rising behaviors. Concern rising behaviors among sickle cell patients was first described by Elander et $\mathrm{al}^{,{ }^{24}}$ It used to describe certain behaviors that may increase healthcare providers' suspicion about the drugseeking condition of sickle cell patients. However, he found these behaviors were associated with real pain seeking relief but not associated with addiction. ${ }^{24}$ Many studies had reported that healthcare providers overstated the percentage of addiction among sickle cell patients. Despite their overstatement, no studies had proven that sickle cell patients had addiction rates more than other patients. On the other hand, sickle cell patients complained frequently that physicians behaved to them as if they were addicted. ${ }^{7}$ Sickle cell patients usually develop pain-coping behaviors such as attention diversion, self-calming, pain ignoring, and reinterpretation of pain..$^{25}$ Additionally, many sickle cell patients try to avoid hospital admissions by managing their pain at home. ${ }^{11}$ These pain-coping behaviors found to be associated with better outcomes. ${ }^{26}$ Unfortunately, healthcare providers may perceive these pain-coping behaviors as drug-seeking behavior. ${ }^{25}$ In our study, we found that emergency and internal medicine providers have a higher concern that drug-seeking behaviors were common among sickle cell patients than pediatric providers. Furthermore, emergency providers were concerned more than those of other departments. In a previous study, more concern about addiction among sickle cell patients was found among emergency providers when compared to hematologists. Approximately, $53 \%$ of ED providers were thinking that more than $20 \%$ of sickle cell patients were addicted while only $23 \%$ of the hematologists were thinking so. ${ }^{21}$ On the other hand, the lower concerns among pediatric providers in our study were supported by Shapiro et al, ${ }^{21}$ study which showed physicians' concerns about drug addiction among pediatric patients were lower than that of adult patients. However, lower concerns about addiction in pediatric patients may reflect reduced use 
of opiates and reduced acute health care utilization than adults with SCD. More healthcare providers' concerns about addiction among sickle cell patients can lead to ineffective pain management. ${ }^{27}$ Ineffective pain management in chronic pain patients can further result in pseudo-addiction syndrome which described first by Weissman and Haddox in $1989 .{ }^{15}$ This syndrome characterized by behavioral changes among the patients such as mistrust, anger, isolation, and depression. Unfortunately, these behaviors can be misunderstood by the healthcare providers as behaviors increasing their concerns about drug addiction among chronic pain patients. ${ }^{15}$ Pseudo-addiction found to adversely affect pain management in the hospital. ${ }^{24}$ Pseudo-addiction was associated with sickle cell patients' dissatisfaction with their pain management and frequent ED visits looking for pain relief. The frequent ED visits following Inadequate pain relief consequently increase healthcare providers' concerns that these repeated visits were for drug addiction and so on. ${ }^{21}$ Previous research found lesser concerns by healthcare providers and more trust in patients' pain complaints were associated with more effective pain control. ${ }^{28}$ In addition, we found more experience in treating sickle cell patients was associated with lower scores in concern rising behavior scale. On the contrary, Singh et al, ${ }^{16}$ found older ER providers were having more scores in concern rising behaviors than the younger ones. He attributes this to the difference between the 2 groups in their education about SCD and also to their higher exposure to sickle cell patients among the older ones. ${ }^{16}$

Study limitations. The inclusion of only healthcare providers in Jazan, KSA hospitals and only from selected departments was the main limitation. No doubt, the inclusion of other departments and other cities where SCD was prevalent might yield more valuable results. Another limitation was that this study cannot fully explain the reasons behind these attitudinal scores. Despite these limitations, we believe that our results can be utilized as a baseline in which interventions and improvement plans could be carried out in the future.

In conclusion, this study highlighted significant levels of attitudes that may negatively affect the care quality of sickle cell patients which furthermore can worsening their conditions. Negative attitudes toward sickle cell patients and high concern about drug-seeking behaviors among them were common findings among physicians and nurses in Jazan, KSA, especially among nurses and ED healthcare providers. These attitudes can be associated with lower quality of sickle cell pain management. The reasons behind these attitudes need to be explored and the quality of services provided to sickle cell patients need to be evaluated more. Improvement of healthcare providers' attitudes toward sickle cell patients through different educational and behavioral interventions is highly recommended as well as the promotion of sickle cell pain management based on the current guidelines such as National Heart, Lung, and Blood Institute's (NHLBI) expert panel report, American Society of Hematology (ASH) pain guidelines.

Acknowledgment. The authors gratefully acknowledge Deanship of Scientific Research, Jazan University, Jazan, Kingdom Saudi Arabia for their financial support of this work [Grant no; FR6-110]. The authors would also like to thank SCRIBENDI (www.scribendi.com) for their English language editing.

\section{References}

1. Kohne E. Hemoglobinopathies. Clinical manifestations, diagnosis, and treatment. Dtsch Aerzteblatt 2011; 108: 532-540.

2. Weatherall DJ, Clegg JB. Inherited haemoglobin disorders: an increasing global health problem. Bull World Heal Organ 2001; 79: 704-712.

3. Diallo D, Tchernia G. Sickle cell disease in Africa. Curr Opin Hematol 2002; 9: 111-116.

4. Alsaeed ES, Farhat GN, Assiri AM, Memish Z, Ahmed EM, Saeedi MY, et al. Distribution of hemoglobinopathy disorders in Saudi Arabia based on data from the premarital screening and genetic counseling program, 2011-2015. J Epidemiol Glob Health 2018; 7: S41-S417.

5. Jastaniah W. Epidemiology of sickle cell disease in Saudi Arabia. Ann Saudi Med 2011; 31:289-293.

6. Hazzazi A, Ageeli M, Alfaqih A, Jaafari A, Malhan H, Bakkar M. Epidemiology and characteristics of sickle cell patients admitted to hospitals in Jazan region, Saudi Arabia. J Appl Hematol 2020; 11: 10.

7. Haywood C, Lanzkron S, Hughes MT, Brown R, Massa M, Ratanawongsa $\mathrm{N}$, et al. A video-intervention to improve clinician attitudes toward patients with sickle cell disease: The results of a randomized experiment. J Gen Intern Med 2011; 26: 518-523.

8. Haywood C, Beach MC, Lanzkron S, Strouse JJ, Wilson R, Park $\mathrm{H}$, et al. A systematic review of barriers and interventions to improve appropriate use of therapies for sickle cell disease. $J$ Natl Med Assoc 2009; 101: 1022-1033.

9. Freiermuth CE, Haywood C, Silva S, Cline DM, Kayle M, Sullivan D, et al. Attitudes toward patients with sickle cell disease in a multicenter sample of emergency department providers. Adv Emerg Nurs J 2014; 36: 335-347.

10. Glassberg JA, Tanabe P, Chow A, Harper K, Haywood C, Debaun MR, et al. Emergency provider analgesic practices and attitudes toward patients with sickle cell disease. Ann Emerg Med. Elsevier Inc 2013; 62: 293-302.

11. Maxwell K, Streetly A, Bevan D. Experiences of hospital care and treatment seeking for pain from sickle cell disease: Qualitative study. Br Med J 1999; 318: 1585-1590.

12. Bender M. Sickle Cell Disease. Adam MP, Ardinger HH PR, editor. Seattle (WA): GeneReviews, 2017. p. 1-35 
13. Steinberg M, Rees DC, Frédéric P. Sickle Cell Disease. $N$ Engl J Med 2017; 376: 1561-1573.

14. Geller AK, O'Connor MK. The sickle cell crisis: a dilemma in pain relief. Mayo Clin Proc 2008; 83: 320-323.

15. Weissman DE, Haddox JD. Opioid pseudoaddiction - an iatrogenic syndrome. Pain 1989; 36: 363-366.

16. Singh AP, Haywood C, Beach MC, Guidera M, Lanzkron S, Valenzuela-Araujo D, et al. Improving emergency providers' attitudes toward sickle cell patients in pain. J Pain Symptom Manage 2016; 51: 628-632.E3.

17. Wright $\mathrm{K}$, Adeosum O. Barriers to effective pain management in sickle cell disease. Br J Nurs 2009; 18: 158-161.

18. Freiermuth CE, Silva S, Cline DM, Tanabe P. Shift in emergency department provider attitudes toward patients with sickle cell disease. Adv Emerg Nurs J 2016; 38: 199-212.

19. Jenerette CM, Pierre-Louis BJ, Matthie N, Girardeau Y. Nurses' Attitudes Toward Patients with Sickle Cell Disease: A Worksite Comparison. Pain Manag Nurs 2015; 16: 173-181.

20. Ratanawongsa N, Haywood C, Bediako SM, Lattimer L, Lanzkron S, Hill PM, et al. Health care provider attitudes toward patients with acute vaso-occlusive crisis due to sickle cell disease: development of a scale. Patient Educ Couns 2009; 76: 272-278.

21. Shapiro BS, Benjamin LJ, Payne R, Heidrich G. Sickle cellrelated pain: Perceptions of medical practitioners. J Pain Symptom Manage 1997; 14: 168-174.
22. Murray N, May A. Painful crises in sickle cell disease - Patients' perspectives. Br Med J 1988; 297: 452-454.

23. Haywood C, Williams-Reade J, Rushton C, Beach MC. Geller G. improving clinician attitudes of respect and trust for persons with sickle cell disease. Hosp Pediatr 2015; 5: 377-384.

24. Elander J, Lusher J, Bevan D, Telfer P, Burton B. Understanding the causes of problematic pain management in sickle cell disease: Evidence that pseudoaddiction plays a more important role than genuine analgesic dependence. J Pain Symptom Manage 2004; 27: 156-169.

25. Gil KM, Abrams MR, Phillips G, Keefe FJ, Kinney TR, Rosse WF, et al. Sickle Cell Disease Pain : Relation of Coping Strategies to Adjustment. J Consult Clin Psychol 1989; 57: 725-731.

26. Gil KM, Williams DA, Thompson RJ, Kinney TR. Sickle cell disease in children and adolescents : the relation of child and parent pain coping strategies to adjustment. J Pediatr Psychol 1991; 16: 643-63.

27. Elander J, Lusher J, Bevan D, Telfer P. Pain management and symptoms of substance dependence among patients with sickle cell disease. Soc Sci Med 2003; 57: 1683-1696.

28. Brookoff D, Polomano R. Treating sickle cell pain like cancer pain. Ann Intern Med 2018; 364-3648. 